\title{
Effects of Credit Policy on Profitability of Manufacturing Firms in Kenya
}

\author{
James N. Kungu ${ }^{1}$, Kenneth L. Wanjau ${ }^{2,}$ Anthony G. Waititu ${ }^{3}$, \\ Geoffrey M. Gekara ${ }^{4}$ \\ Department of Business, Nyandarua Institute of Science and Technology, Nyahururu, Kenya \\ School of Human Resource Development, Jomo Kenyatta University of Agriculture and Technology, Nairobi, Kenya \\ School of Actuarial Science, Jomo Kenyatta University of Agriculture and Technology, Nairobi, Kenya \\ School of Business, East African University, Nairobi, Kenya
}

\begin{abstract}
This paper considered the effects of credit policy on profitability of manufacturing firms in Kenya. The study looked at the elements that constitute the credit policy; credit terms, collection efforts, credit period and credit standards. A descriptive research design was used to collect the data from the field and a stratified random sampling technique was used to come up with a sample of 81 manufacturing firms. A questionnaire was used to collect data from 81 manufacturing firms in Nairobi industrial area and its environs in Kenya. However, only 71 questionnaires were returned. The chief finance officers of the manufacturing firms were requested to fill in the questionnaire. Both descriptive and inferential analyses were done. Analysis of Variance (ANOVA) and regression analysis were used to test the hypothesis. The results show that there is a positive relationship between profitability and credit policy in the manufacturing firms in Kenya (0.304). Credit policy explains only 9.2\% of the profitability in the manufacturing firms in Kenya. $90.8 \%$ of the variation in profitability is explained by other factors. The findings of the study revealed that the way credit policy is designed impacts on the profitability of manufacturing firms. Therefore, we recommend that the finance managers of manufacturing firms regularly review the credit policy of their firms to ensure that they are ideal and result in increased profitability.
\end{abstract}

Key words: (Accounts Receivables, Credit Policy, Manufacturing Firms, Profitability, Trade Credit)

\section{Introduction}

Business enterprises today use trade credit as a prominent strategy in the area of marketing and financial management. Thus, trade credit is necessary in the growth of the businesses. When a firm sells its products or services and does not receive cash for it, the firm is said to have granted trade credit to its customers. Trade credit thus creates accounts receivables which the firm is expected to collect in future. Accounts receivables are executed by generating an invoice which is delivered to the customer, who in turn must pay within and with the agreed terms. The accounts receivables are one of the largest assets of a business enterprise comprising approximately $15 \%$ to $20 \%$ of the total assets of a typical manufacturing firm (Dunn, 2009). Investment in receivables takes a big chunk of organization's assets. These assets are highly vulnerable to bad debts and losses. It is therefore necessary to manage accounts receivables appropriately.

Trade credit is very important to a firm because it helps to protect its sales from being eroded by competitors and also attracts potential customers to buy at favorable terms. As long as there is competition in the industry, selling on credit becomes inevitable. A business will lose its customers to competitors if it does not extend credit to them. Thus, investment in accounts receivables may not be a matter of choice but a matter of survival (Kakuru, 2001). Given that investment in receivables has both benefits and costs; it becomes important to have such a level of investment in receivables at the same time observing the twin objectives of liquidity and profitability.

To remain profitable, businesses must ensure proper management of their receivables (Foulks, 2005). The management of receivables is a practical problem. Businesses can find their liquidity under considerable strain if the levels of their accounts receivables are not properly regulated (Samuels and walkers, 1993). Thus management of accounts receivables is important, for without it; receivables will build up to excessive levels leading to declining cash flows. Poor management of receivables will definitely result into bad debts which lowers the business' profitability.

Credit policy is the most popular medium of managing and regulating receivables. To ensure optimal investment in receivables, a business is required to have an appropriate credit policy. Credit policy is designed to minimize costs associated with credit while maximizing the benefits from it. Credit policy refers to guidelines that spell out how to decide which customers are sold on open account, the exact payment terms, the limits set on outstanding balances and how to deal with delinquent accounts (Krueger, 2005). According to (Pandey, 2007; Atkinson, Kaplan \& Young, 2007 and Brigham, 1985) credit policy is defined in the manner as 
the combination of such terms as credit period, credit standards, collection period, cash discounts and cash terms. Therefore, despite the fact that organizations have different credit policies, the content of these policies must touch on credit period, credit standards, collection period and credit terms.

Credit policy is either lenient or stringent. A lenient credit policy tends to give credit to customers on very liberal terms and standards such that credit is granted for longer periods even to those customers whose credit worthiness is not well known. A stringent credit policy on the other hand is restrictive and allows credit only to those customers whose credit worthiness have been ascertained and are financially strong. There are no two organizations with a similar credit policy. Whether lenient or stringent credit policy is adopted by an organization, it must ensure that it attracts and retains good customers, without having a negative impact on the cash flow (Kalunda, Nduku \& Kabiru, 2012).

Miller (2008) argues that there are four reasons why organizations have written credit policies. First, the undertaking of managing receivables is a serious responsibility. It involves limiting bad debts and improving cash flow. Outstanding receivables become a major asset of a firm and therefore require a reasoned and structured approach and therefore credit management is necessary. Second, a credit policy assures a degree of consistency among departments. By written down what is expected, the aims of the company (whether marketing, production or finance) will realize that they have a common set of goals. Also, a written policy can delineate each department functions so that duplication of effort and needless friction are avoided. Third, it provides for a consistent approach among customers. Decision making becomes a logical function based on predetermined parameters. This simplifies the decision process and yields a sense of fairness that will only improve customer relations. Finally, it can provide some recognition of the credit department as a separate entity, one which is worthy of providing input into the overall strategy of the firm. This allows the department to be an important resource to top management (Kalunda et al., 2012).

According to Chee and Smith (1999) credit policy is multi-faceted. There are two basic forms of trade credit: the simpler form, net terms, specifies that full payment is due within a certain period after delivery. For example, 'net 30' means full payment is due 30 days after invoice; after that the buyer is in default. Invoicing normally occurs either around the delivery or at the end of a billing cycle. The more complex form of credit, two part terms, has three basic elements: the discount percentage, the discount period and the effective interest rate. The most common two part terms are ' $2 / 10$ net 30 '. This means a $2 \%$ discount for payment within 10 days and a net period ending on day 30 . As with net terms; the buyer is in default if payment is not made by the end of the net period.

Due to the speed in which technology is changing and the dynamics in business caused by changes in their internal and external environment, the ways in which businesses are conducted today differ significantly from yester years. Therefore, for a credit policy to be effective it should not be static (Szabo, 2005 and Ojeka, 2012). Credit policy requires to be reviewed periodically to ensure that the organizations operate in line with the competition. This will ensure further that sales and credit departments are benefiting.

Organizations differ so do their credit policies. While most companies have their own policies, procedures and guidelines, it is unlikely that any two firms will define them in a similar manner. However, no matter how large or small an organization is and regardless of the differences in their operations or product, the effects of credit policies usually bring about similar consequences. Effects of a credit policy are either good enough to bring growth and profits or bad enough to bring declination and losses. This similarity is as a result of the aim of every manager which is to collect their receivables efficiently and effectively, thus maximizing their cash in flows (Ojeka, 2012).

The purpose of the study was to determine whether credit policy influences profitability of manufacturing companies in Kenya. Both null and alternative hypothesis were tested:

$\mathrm{H}_{01}$ : Credit policy does not significantly influence on the profitability of manufacturing

firms in Kenya

$\mathrm{H}_{11}$ : Credit policy has a significant influence on the profitability of manufacturing firms in Kenya

\section{Literature Review}

In this section, we summarize two relevant theories related to credit policy and three most recent researches. The transaction motive theory of trade credit suggests that businesses should provide trade credit by reducing the cost of administering invoices between suppliers and buyers undertaking regular exchanges of goods and services (Nilsen, 2002). Manufacturing firms face strong seasonality and uncertainty in the demand for their products and may have to build up large inventories in order to maintain their production levels. By offering credit, firms may be able to manage their inventory positions better and reduce warehousing costs. Financing advantage theories on the other hand suggest that the firm that provides credit to its customers has an advantage over other credit providers in assessing the credit worthiness of his customers (Chee \& Smith, 1999; Nilsen, 2002). 
It may be noted that credit policy is a rare area of research. Kalunda et al. (2012) carried out a study on pharmaceutical manufacturing companies in Kenya and their credit risk management practices. They used a semi structured questionnaire to solicit information from finance managers or credit controller. They found that the most important factors considered in establishing a credit policy is the financial stability of the customer and existing credit policy. Most widely used credit risk management practices are debt collectors, letter of credit, and credit insurance and factor of debt. When dealing with difficult customers accounts are put on hold and stop future sales till the account is settled

Ojeka (2012) studied four manufacturing companies in Nigeria. He used annual reports and accounts of selected companies as well as questionnaire. His findings revealed that when a company's credit policy is favourable, liquidity is at a desirable level. He further found that the companies that monitor and regularly review their credit policy and reduce cash discount allowances perform quite well in terms liquidity position and profitability.

Uremadu, Egbido and Enyi (2012) carried out a study in Nigeria on working capital management, liquidity and corporate profitability in the manufacturing firms that were quoted. The study used a cross sectional time series data for the period 2005 - 2006. Debtors' collection period was used as proxy or credit policy and represented the length of time it takes the companies to collect proceeds of sales from their debtors. The study established a distorted and non significant relationship of debtors' collection period with the level of corporate profitability cum liquidity among quoted companies in Nigeria

\section{Methodology}

The study used descriptive research design to discover the association between profitability and credit policy. A stratified random sampling technique was used to come up with a sample of 81 companies from the twelve sub sectors of manufacturing companies in Kenya. A structured questionnaire was used to collect data from 81 chief finance officers of the sample companies. The SPSS program was used to analysis the data.

In order to ensure that the research tool was reliable, a reliability test was done. The results indicated Cronbach's alpha of 0.828 . This is more than the threshold of 0.7 as advocated by Nunnally and Berstein (1994) and Sekeran (2008). Factor analysis was also done to ensure that all questions made sense. Factor analysis ensured that questions that required further analysis had a factor loading of more than 0.4 as advocated by David, Patrick and Philip (2010). All the questions had a factor load of between 0.538 and 0.873 and therefore were considered for further analysis.

Two steps were followed in the analysis of the data; descriptive and quantitative. Descriptive analysis was the first step in the analysis. This showed the percentages, mean and standard deviation of different items in the study. The quantitative analysis followed. Pearson correlation, ANOVA and regression analysis were used. Pearson correlation showed the degree of association between profitability and credit policy.

\section{Descriptive Analysis}

$\begin{array}{lcc}\text { Response } & \text { Respondents } & \text { Percentage (\%) } \\ \text { Returned } & 71 & 87.7 \\ \text { Not Returned } & 10 & 12.3 \\ \text { Total Distributed } & \mathbf{8 1} & \mathbf{1 0 0 . 0}\end{array}$

Table 1 shows that a total number of 81 questionnaires were administered to the chief finance officers of manufacturing firms, in Nairobi industrial area and its environs. 71 questionnaires were returned which represents $87.7 \%$ of all questionnaires administered. 10 questionnaires were not returned and this represents $12.3 \%$ of all questionnaires.

Table 2: Length of time allowed to customers on credit sales has an influence on sales

$\begin{array}{lllllllll}\text { Response } & \text { Strong } & \text { Disagree } & \text { Undecided } & \text { Agree } & \begin{array}{l}\text { Strongly } \\ \text { Agree }\end{array} & \text { Total } & \text { Mean } & \begin{array}{l}\text { Standard } \\ \text { Disagree }\end{array} \\ & 1 & 4 & 7 & 25 & 34 & 71 & 4.23 & 0.944 \\ \text { Frequency } & 1 & 4 & 7.9 & 35.2 & 47.9 & 100 & & \end{array}$

The table 2 shows that $1.4 \%$ of the respondents strongly disagreed with the statement that the length of time the customers are allowed on credit sales has an influence on sales, 5.6\% disagreed 9.9\% were unsure, $35.2 \%$ 
agreed and $47.9 \%$ strongly agreed with the statement. Majority were of the opinion that the length of time the customers are allowed on credit sales has an influence on sales. The question had a mean of 4.23 and a standard deviation of 0.944 . This means that most of the responses were 4, indicating that respondents agreed to the statement that the length of time the customers are allowed on credit sales has an influence on sales.

\section{Table 3: Firms consider the production cycle when setting credit standards}

$\begin{array}{lcccccccc}\text { Response } & \begin{array}{l}\text { Strong } \\ \text { Disagree }\end{array} & \text { Disagree } & \text { Undecided } & \text { Agree } & \begin{array}{c}\text { Strongly } \\ \text { Agree }\end{array} & \text { Total } & \text { Mean } & \begin{array}{c}\text { Standard } \\ \text { Deviation }\end{array} \\ \text { Frequency } & 1 & 5 & 6 & 33 & 26 & 71 & 3.73 & 0.928 \\ \text { Per cent } & 1.4 & 5.6 & 9.9 & 35.2 & 47.9 & 100 & & \end{array}$

Table 3 shows that $1.4 \%$ of the respondents strongly disagreed with the statement that the firms consider the production cycle when setting credit standards, $7.0 \%$ disagreed, $8.5 \%$ were unsure, $46.5 \%$ agreed and $36.6 \%$ strongly agreed with the statement. Majority were of the opinion that the firms consider the production cycle when setting credit standards. The question had a mean of 3.73 and a standard deviation of 0.928 . This means that most of the responses were 4, indicating that respondents agreed to the statement that the firms consider the production cycle when setting credit standards.

\begin{tabular}{|c|c|c|c|c|c|c|c|c|}
\hline Response & $\begin{array}{l}\text { Strong } \\
\text { Disagree }\end{array}$ & Disagree & Undecided & Agree & $\begin{array}{l}\text { Strongly } \\
\text { Agree }\end{array}$ & Total & Mean & $\begin{array}{l}\text { Standard } \\
\text { Deviation }\end{array}$ \\
\hline Frequency & 0 & 7 & 4 & 32 & 28 & 71 & 4.14 & 0.915 \\
\hline Per cent & 0 & 9.9 & 5.6 & 45.1 & 39.4 & 100 & & \\
\hline
\end{tabular}

Table 4 shows that $9.9 \%$ of the respondents disagreed with the statement that firms investigate credit worthiness of their customers, $5.6 \%$ were unsure, $45.1 \%$ agreed and $39.4 \%$ strongly agreed with the statement. Majority were of the opinion that the firms investigate credit worthiness of their customers. The question had a mean of 4.14 and a standard deviation of 0.915 . This means that most of the responses were 4 , indicating that respondents agreed to the statement that the firms investigate the credit worthiness of their customers.

Table 5: Firms set credit terms that stipulate credit period extension

$\begin{array}{ccccccccc}\text { Response } & \begin{array}{c}\text { Strong } \\ \text { Disagree }\end{array} & \text { Disagree } & \text { Undecided } & \text { Agree } & \begin{array}{c}\text { Strongly } \\ \text { Agree }\end{array} & \text { Total } & \text { Mean } & \begin{array}{c}\text { Standard } \\ \text { Deviation }\end{array} \\ \text { Frequency } & 13 & 7 & 6 & 31 & 14 & 71 & 3.37 & 1.396 \\ \text { Per cent } & 18.2 & 9.9 & 8.5 & 43.7 & 19.7 & 100 & & \end{array}$

Table 5 shows that $18.2 \%$ of the respondents strongly disagreed with the statement that their firms set credit terms that stipulate credit period extension, 9.9\% disagreed, $8.5 \%$ were unsure, $43.7 \%$ agreed and $19.7 \%$ strongly agreed with the statement. Majority were of the opinion that the firms consider the production cycle when setting credit standards. The question had a mean of 3.37 and a standard deviation of 1.396. This means that most of the responses were 3 , indicating that the number of respondents who agreed with the statement is equal to the number of the respondents who disagreed.

Table 6: Firms allow cash discounts to their customers to induce them pay promptly

$\begin{array}{lcccccccc}\text { Response } & \begin{array}{c}\text { Strong } \\ \text { Disagree }\end{array} & \text { Disagree } & \text { Undecided } & \text { Agree } & \begin{array}{c}\text { Strongly } \\ \text { Agree }\end{array} & \text { Total } & \text { Mean } & \begin{array}{c}\text { Standard } \\ \text { Deviation }\end{array} \\ \text { Frequency } & 2 & 3 & 16 & 29 & 21 & 71 & 3.9 & 0.973 \\ \text { Per cent } & 2.8 & 4.2 & 22.5 & 40.8 & 29.7 & 100 & & \end{array}$

Table 6 shows that $2.8 \%$ of the respondents strongly disagreed with the statement that their firms allow cash discounts to their customers to induce them pay promptly, $4.2 \%$ disagreed, $22.5 \%$ were unsure, $40.8 \%$ agreed and $29.7 \%$ strongly agreed with the statement. Majority were of the opinion that their firms consider the production cycle when setting credit standards. The question had a mean of 3.9 and a standard deviation of 0.973. This means that most of the responses were 4, indicating that firms allow cash discounts to their customers to induce them pay promptly. 
Table 7: Period between credit sales and collection period is more than $\mathbf{3 0}$ days

$\begin{array}{lllllllll}\text { Response } & \begin{array}{l}\text { Strong } \\ \text { Disagree }\end{array} & \text { Disagree } & \text { Undecided } & \text { Agree } & \begin{array}{l}\text { Strongly } \\ \text { Agree }\end{array} & \text { Total } & \text { Mean } & \begin{array}{l}\text { Standard } \\ \text { Deviation }\end{array} \\ \text { Frequency } & 3 & 15 & 10 & 21 & 22 & 71 & 3.62 & 1.246 \\ \text { Per cent } & 4.2 & 21.1 & 14.1 & 29.6 & 31.0 & 100 & & \end{array}$

Table 7 shows that $4.2 \%$ of the respondents strongly disagreed with the statement that the period between credit sales and collection period is longer than 30 days, $21.1 \%$ disagreed, $14.1 \%$ were unsure, $29.6 \%$ agreed and $31 \%$ strongly agreed with the statement. Majority were of the opinion that their firms consider the production cycle when setting credit standards. The question had a mean of 3.62 and a standard deviation of 1.246. This means that most of the responses were 4, indicating that the period between credit sales and collection period is more than 30 days.

Table 8: Firm's overall credit policy has the ability to increase sales

$\begin{array}{lcccccccc}\text { Response } & \begin{array}{l}\text { Strong } \\ \text { Disagree }\end{array} & \text { Disagree } & \text { Undecided } & \text { Agree } & \begin{array}{c}\text { Strongly } \\ \text { Agree }\end{array} & \text { Total } & \text { Mean } & \begin{array}{c}\text { Standard } \\ \text { Deviation }\end{array} \\ \text { Frequency } & 1 & 3 & 9 & 28 & 30 & 71 & 4.17 & 0.910 \\ \text { Per cent } & 1.4 & 4.2 & 12.7 & 39.4 & 42.3 & 100 & & \end{array}$

Table 8 shows that $1.4 \%$ of the respondents strongly disagreed with the statement that their firms' overall credit policy have an ability to increase sales, $4.2 \%$ disagreed, $12.7 \%$ were unsure, $39.4 \%$ agreed and $42.3 \%$ strongly agreed with the statement. Majority were of the opinion that the firms' overall credit policies have the ability to increase sales. The question had a mean of 4.17 and a standard deviation of 0.910 . This means that most of the responses were 4 , indicating that the firms' credit policies have the ability to increase sales.

\section{Correlation Analysis}

Table 9 indicates that there is a positive significant linear relationship between credit policy and profitability of manufacturing firms in Kenya. This relationship has been illustrated by correlation coefficient of 0.304 at 0.01 significant levels. This implies that there is a weak significant positive relationship between credit policy and profitability of manufacturing firms in Kenya. The results conform to the previous studies done by (Gill, Biger\&Mathur, 2010) who found that firms that maintain accounts receivables at optimal level are able to create and maximize their profits.

Table 9: Correlation between Credit Policy and Profitability

\begin{tabular}{clcc}
\multirow{2}{*}{ Profitability } & Profitability & Credit Policy \\
& Pearson Correlation & 1 & \\
Significant $(2$ tailed $)$ & - & 1 \\
Credit Policy & Pearson Correlation & $0.304 * *$ & - \\
& Significant $(2$ tailed $)$ & 0.010 & Correlation is significant at 0.01 level $(2-$ tailed $)$
\end{tabular}

\section{Regression Analysis}

Table 10 provides the $R$ and $R^{2}$ value representing the sample correlation. In this case, $R^{2}$ was $9.2 \%$ which indicates that credit policy explains the $9.2 \%$ of variation in profitability. The other $90.8 \%$ of the variation in profitability is explained by other factors not in the regression.

\section{Table 10: Model summary for Credit Policy}

$\begin{array}{ccccc}\text { Model } & \mathrm{R} & \mathrm{R} \text { Square } & \text { Adjusted R Square } & \text { Std. Error of the Estimate } \\ 1 & .304^{\mathrm{a}} & .092 & .079 & 5.66293 \\ \text {. Predictors: (Constant), Credit Policy } & & \end{array}$


ANOVA results in Table 11 indicate that regression model predicts the profitability significantly well. This indicates the statistical significance of the regression model that was applied. An F statistic of 7.028 indicated that the model was significant. This was supported by the p-value of $0.010^{\mathrm{a}}$. It indicates thatthe overall model applied can statistically predict the profitability.

\section{Table 11: ANOVA for Credit Policy and Profitability}

\begin{tabular}{llllcrr} 
Model & & Sum of Squares & df & Mean Square & F & Sig. \\
1 & Regression & 225.366 & 1 & 225.366 & 7.028 & $.010^{\mathrm{a}}$ \\
& Residual & 2212.745 & 69 & 32.069 & & \\
& Total & 2438.111 & 70 & & & \\
\multicolumn{2}{l}{ a. Predictors: (Constant), Credit Policy } & & & & \\
b. Dependent Variable: Profitability & &
\end{tabular}

Table 12 provides the information needed to predict profitability from credit policy. Both the constant and credit policy contribute significantly to the model. The regression equation is presented as follows:Profitability = $11.765+0.232$ (Credit Policy)

From table 12 below there is a positive unstandardized beta co-efficient of 0.232 as indicated by the coefficient matrix. For the regression line to be significant, the following alternative hypothesis has to be true:

$$
\begin{aligned}
& \mathrm{H}_{0}: \beta_{1}=0 \\
& \mathrm{H}_{1}: \beta_{1} \neq 0
\end{aligned}
$$

Table 12 shows that the p-value is less than 0.05 . Therefore, in this case the null hypothesis was rejected and concluded that the alternative hypothesis that; $\beta_{1} \neq 0$, which implies that credit policy has a significant influence on profitability of manufacturing firms in Kenya.

\section{Table 12: Prediction of Profitability from Credit Policy}

\begin{tabular}{llccccc} 
& \multicolumn{5}{c}{ Unstandardized Coefficients } & $\begin{array}{c}\text { Standardized } \\
\text { Coefficients }\end{array}$ \\
Model & & B & Std. Error & Beta & t & Sig. \\
1 & (Constant) & 11.765 & 3.137 & & 3.751 & .000 \\
& Credit Policy & .232 & .088 & .304 & 2.651 & .010
\end{tabular}

a. Dependent Variable: Profitability

\section{Conclusion and Recommendations}

Most of the manufacturing firms companies in Kenya have credit policies. It can therefore be expected that the way in which credit policy is designed will have a significant impact on profitability of these firms. The study a significant positive relationship between credit policy and profitability for the sample of Kenyan manufacturing firms exists. These results suggest that managers can create value for their shareholders by designing, implementing and managing ideal credit policies.

Regarding the hypothesis, it can be concluded that the alternative hypothesis $\left(\mathrm{H}_{1}\right)$ that credit policy significantly influence profitability of manufacturing firms in Kenya is accepted and thenull hypothesis $\left(\mathrm{H}_{0}\right)$ is rejected.The conclusions are in confirmation with (Ojeka, 2012) who found a strong positive relationship between credit policy and profitability.

There is much to be done about credit policy in Kenya in future. It is suggested that further research be conducted on the topic with different manufacturing firms and extending the sample size. The scope of the research may be extended to other components of working capital management; accounts payable practices, working capital levels, liquidity and inventory control.

\section{Suggested Areas of Further Research}

- Research on other areas that affect profit making in manufacturing firms

- Effect of credit policy on economic growth

- Credit policy and information technology in cost minimization in manufacturing firms 


\section{Reference}

[1]. Atkinson, A. A., Kaplan, R. S. \& Young, S. M. (2007). Management Accounting. New Jersey: Prentice Hall.

[2]. Brigham, E. F. (1985). Fundamentals of Financial Management. New York: Dryden Publishers

[3]. Chee, K. \& Smith, R. (1999). Evidence on the determinants of credit terms used in Inter-firm Trade. Journal of Finance, Blackwell Publishers

[4]. David, F.G., Patrick, W. S., Philip, C. F. \& Kent, D. S. (2010). “Business Statistics“. New Jersey: Pearson Publishers

[5]. Dunn, M. (2009). "Why you need a credit policy". Retrieved July 13, 2013. From http://www.entreprenuer.com/columnists/michelledunn/archive202424.html

[6]. Foulks, L. (2005).Financial Management and Control, London: FTC Fouls Lynch Publications

[7]. Gill, A., Biger, N. \&Mathur, N. (2010). The relationship between working capital management and profitability: evidence from the United States. Business and Economics Journal, Volume 2010: BEJ-10

[8]. Kakuru, J. (2001).Financial Decisions and the Business, $2^{\text {nd }}$ edition, Kampala: The business publishing group

[9]. Kalunda, E., Nduku, B. \&Kabiru, J. (2012). Pharmaceutical Manufacturing Companies in Kenya Management Practices, Research Journal of Finance and Accounting, Vol. 3, No. 5, pp. 159- 167

[10]. Miller, C. (2008). "Is it time to review your credit policy".Retrieved November 29, 2013 from www.creditresearchfoundationonline.com

[11]. Nilsen, J. (2002). Trade Credit and the Bank Lending Channel. Journal of Money, Credit and Banking, Volume 10, Issue 3

[12]. Nunnally, J. C. (1978). Psychometric Theory, New York: McGraw-Hill.

[13]. Ojeka, S. A. (2012). Credit Policy and its effects on Liquidity: A study of selected manufacturingcompanies in Nigeria, the Journal of Commerce, Vol. 3, No. 3, pp. 10-19

[14]. Pandey, I. M. (2007). "Financial Management", $10^{\text {th }}$ Edition. New Delhi: Vikas Publishing House Pvt. Limited.

[15]. Sekaran, U. (2008). Research Methods for Business: A Skill building Approach, New York: John Wiley \& Sons, Inc.

[16]. Szabo, P. T. (2005). “A road map for effective credit policy collective wisdom magazine", Vol. No. 20, retrieved June 26, 2013 from $\underline{w w w . s c i e n c e d i r e c t . c o m}$ 